\title{
The Original "Cybernetic Serendipity" Special Issue of Studio International to Be Reprinted
}

\author{
Arts Editorial Office
}

MDPI AG, St. Alban-Anlage 66, 4052 Basel, Switzerland; arts@mdpi.com

Received: 28 March 2018; Accepted: 29 March 2018; Published: 2 April 2018

check for updates

Studio International (Studio International 2018), the now on-line successor to print art magazine The Studio, is planning a late April 2018 50th anniversary reprinting of its Special Issue dedicated to the historic 1968 "Cybernetic Serendipity" techno-art exhibition (Benavides 2018a). Originally published in July of 1968 (Benavides 2018b) —one month before the London opening of the show itself-and edited by curator Jaisa Reichardt, the lengthy (104 pages), lavishly-illustrated (albeit in black and white) Special Issue featured a cover designed by Franciszka Themerson (Figure 1); an introduction by Ms. Reichardt; an overview of cybernetics and its founder, Norbert Wiener; separate sections dedicated to the newly-established connections between the computer and music, dance, poetry, painting, film, architecture, and graphics; a glossary; and a bibliography (Reichardt 1968a).

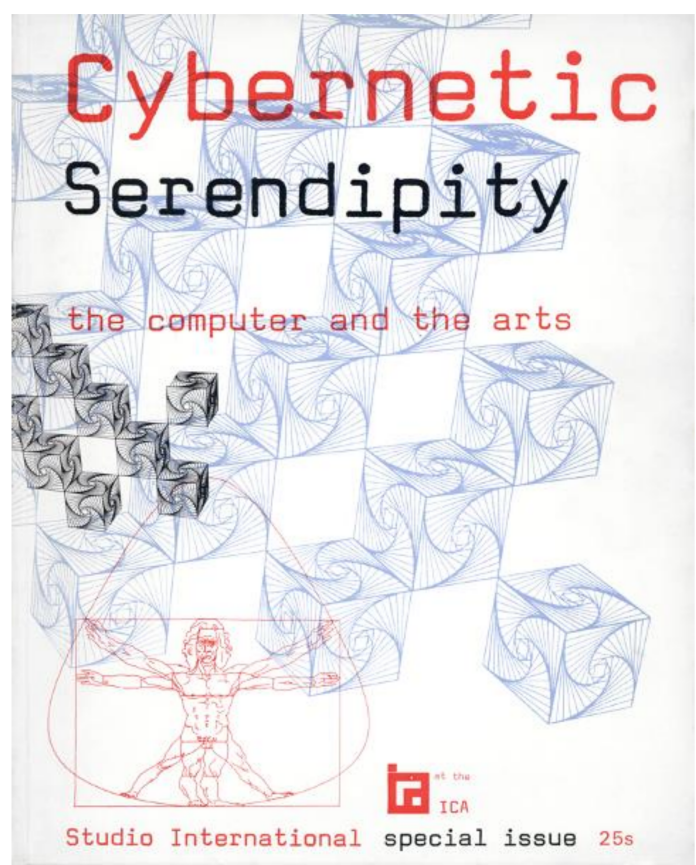

Figure 1. Cover of the Studio International Special Issue "Cybernetic Serendipity: The Computer and the Arts". Design by Franciszka Themerson. (c) 1968 Studio International and used by permission.

The Cybernetic Serendipity show itself, as one of the early and influential techno-art exhibitions-along with "Artist versus Machine" of 1954 (Grieve 2005); "Bewogen Beweging" of 1961 (Hultén 1961); and "The Machine as seen at the end of the Mechanical Age" of 1968 (Hultén 1968) - opened at the ICA (Institute of Contemporary Arts) in London, where it ran from 2 August to 20 October 1968; it then moved to the Corcoran Gallery of Art in Washington D.C., running there from 16 July to 31 August 1969; and it moved finally to the recently founded Exploratorium in San 
Francisco, where it ran from 1 November to 18 December 1969. The show featured a comprehensive assortment of pioneer techno-artists including Edward Ihnatowicz, Liliane Lijn, Gustav Metzger, Nam June Paik, Nicolas Schöffer, and Jean Tinguely, and as represented by a number of their more noteworthy pieces including Paik's Robot K-456 (1964); Schöffer's Cysp-1 (1956); and Tinguely's Méta-Matic (1961) (Reichardt 1968b; Mason 2018). It also included works by engineers, mathematicians, composers and poets, an impression of all of which can be gathered from an existing 1968 video narrated by Ms. Reichardt (Reichardt 1968c). Ms. Reichardt also went on to serve as the editor of a book, Cybernetics, Art and Ideas (Reichardt 1971), extending this study of the relationship between cybernetics and creative experimentation. The exhibition, moreover, has exerted a lasting scholarly influence: in his recent and comprehensive Machine Art of the Twentieth Century, Andreas Broeckmann has made a point of noting "the exceptional historical significance of 'Cybernetic Serendipity'” (Broeckmann 2016).

Acknowledgments: The author would like to thank Miguel Benavides, Editor of Studio International, for sharing news of the reprint with us.

Conflicts of Interest: The author declares no conflicts of interest.

\section{References and Notes}

Benavides, Miguel. 2018a. Editor, Studio International. Personal communication.

Benavides, Miguel. 2018b. Cybernetic Serendipity 50th Anniversary. Studio International, January 1. Available online: http:/ / www.studiointernational.com/index.php/cybernetic-serendipity-50th-anniversary (accessed on 22 March 2018).

Broeckmann, Andreas. 2016. Machine Art in the Twentieth Century. Cambridge: The MIT Press, p. 292, n. 60.

Grieve, Alastair. 2005. Constructed Abstract Art in England after the Second World War: A Neglected Avant-Garde. New Haven and London: Yale University Press. The information herein regarding the exhibition is of considerable importance inasmuch as the original catalog has been lost. The exhibition took place at the Building Center, London, 19 May-9 June 1954.

Hultén, Pontus, ed. 1961. Bewogen Beweging, exhibition catalog; 10 March-17 April 1961. Amsterdam: Stedelijk Museum; traveled to Moderna Museet, Stockholm under the name Rörelse Konsten, 16 May-10 September 1961; and finally to the Louisiana Museum, near Copenhagen under the name Bevægelse i kunsten, 22 September-22 October 1961.

Hultén, Pontus, ed. 1968. The Machine as Seen at the End of the Mechanical Age, Exhibition Catalogue; 27 November 1968-9 February 1969. New York: Museum of Modern Art.

Mason, Catherine. 2018. Cybernetic Serendipity: History and Lasting Legacy. Studio International, March 11. Available online: http:/ /www.studiointernational.com/index.php/cybernetic-serendipity-history-andlasting-legacy (accessed on 22 March 2018).

Reichardt, Jasia, ed. 1968a. Cybernetic Serendipity: The Computer and the Arts. Studio International Special Issue. July. Available online: http:/ /www.studiointernational.com/flipbookCyberneticSerendipity / StudioInternationalCyberneticSerendipity-1968.html (accessed on 22 March 2018).

Reichardt, Jasia. 1968b. 'Cybernetic Serendipity'-Getting Rid of Preconceptions. November, pp. 176-77. Available online: http:/ / www.studiointernational.com/index.php/cybernetic-serendipity-getting-rid-ofpreconceptions-jasia-reichardt (accessed on 25 March 2018).

Reichardt, Jasia. 1968c. Cybernetic Serendipity (ICA)—Late Night Lineup. Available online: https://www. youtube.com/watch?v=n8TJx8n9UsA (accessed on 25 March 2018).

Reichardt, Jasia, ed. 1971. Cybernetics, Art and Ideas. London: Studio Vista Limited, Greenwhich: New York Graphic Society Ltd.

Studio International. 2018. Available online: http:/ / www.studiointernational.com (accessed on 22 March 2018).

(C) 2018 by the author. Licensee MDPI, Basel, Switzerland. This article is an open access article distributed under the terms and conditions of the Creative Commons Attribution (CC BY) license (http://creativecommons.org/licenses/by/4.0/). 